\title{
PROMOTING WRITING EXPERIENCES THROUGH LEARNING COMMUNITY TO TRIGGER STUDENTS IN WRITING
}

\author{
Moh. Yamin \\ Email:moh_yamin@ulm.ac.id \\ English Department, Faculty of Teacher Training and Education, \\ Lambung Mangkurat University \\ Banjarmasin, Indonesia
}

\begin{abstract}
This study aims at discussing the importance of promoting writing experiences through learning community to trigger students in writing. This is a review study with descriptive analysis method which described and discussed the related literature studies. These deal with writing experiences as the core to write in that there is no experience, there is no writing. Learning community used in this study is the learning facility so that the students can learn how to write. The more active the students are in learning community, the more knowledge and experience of writing they will get.
\end{abstract}

Keywords: Writing Experiences, Learning Community, Writing

\section{INTRODUCTION}

Everyone has the unique way to write and the uniqueness is the trait that the difference in way of writing is something given. The difference of writing and how to write should be understood as the result of life experience. It means that writing experience everyone has is not the same. Some people say that writing an article should be started by determining the title; other considers that writing must start from making outline, theme, content, and so forth (Okari, 2016). The difference in getting the point of view is gotten because of different experience in facing the problem that will be written (Yu Liao, 2017). Every problem to discuss and to write has its situation so that it cannnot be treated similiarly. Every problem to write attends with the core problem so that it is necessary to read it critically. Reading critically means that everyone should have the different approach in reading the problem and situation (Javadi-Safa, 2018). By reading it comprehensively and hollistically, it helps to give the way of understanding the problem. Whatever the situation and condition are, writing experiences they have are the strength to strengthen the commitment and motivation to be able to learn in writing.

Writing experience is the step to have the real experience how to write. By having writing experience, it teaches to be able to write based on the topic, situation, and condition. The same topic but in different situation and condition determines the pattern in starting to elaborate and to discuss (Behar-Horenstein et all, 2016). Principally, writing does not only deal with the topic to discuss, but also to explain and elaborate in detail. The writing competence will exist when having writing experience. More involvement in writing means more experiences got and this will increase the strength in discussing and 
elaborating the topic. Consequently, the writing competence refers to the more practice in writing. It means that anyone who is involved in writing tries to actualize the ideas. By writing the ideas into the paper, the writing experiences appear.

Because writing is an experience, it is important to state that writing is the concrete activity involving the mind and logic in discussing and elaborating the topic. The capacity to think critically is required to have and to use in this context. Writing is the thought work; it obliges the person to prepare the knowledge role in discusing and elaborating the topic systematically. Writing is a thinking process in which it works to read the problem, to illustrate the problem, to give any detail information about the problem, and to be explained by giving the reasons about the importance of discussing the problem. Therefore, writing as thinking process attends to respond the situation and condition in a real manner so that it appears for discussion. It means that writing experience in any real situation and condition should be told by anyone for those who involved in order to share the writing experience. Writing experience by telling and sharing to others will be the learning source for all (Javadi-Safa, 2018).

Based on such consideration, it is important to discuss the importance of promoting writing experiences through learning community to trigger students in writing. Promoting writing experiences mean that each students in learning community share their writing experiences so that each of them can learn each other relating to difficulty in writing and strategy in writing dealing with determining the topic, starting to write, and so forth.

\section{METHOD}

This is a review study with analytic descriptive method through describing and discussing the related literature studies. Furthermore, it was done by making any findings and results of the previous researches as the content and context in analysis. What to discuss is the same and similiar research theme-based on the finding and discussion, so that this research actually attends to discuss any previous researches to make the new perspective in understanding the importance of writing experience through learning community. The new perspective towards the learning community to trigger students in writing can be studied from the previous researches. Therefore, this study does not limit the number of research results to analyze. More research results to analyze means more studies to get the findings so that those enrich the discussions.

\section{FINDING}

Schwehm, Saxton, and Stuckey (2017) state that providing engagement and community in learning to write gives a positive classroom experience towars students. They are able to partake in the learning process actively and their participation triggers them to be able to learn together because their position in learning community is to 
interact each other, share their experience in learning, and motivate each other. In the learning process through engagement and community, all students become the ones to open themselves in learning. What they do not know and do not understand dealing with the writing difficulties is delivered and discussed. The instructor's attendance in this engagement and community has the main role to facilitate the learners to be more active and it seems that there are no constraints and barriers because all learners have the same goal to learn.

Deveci (2018) states that collaborative writing experience is something positive for shaping the learners' motivation in learning. It contributes to English language and teamwork skill in writing that is sharpened. Promoting the active atmosphere and innovation in learning assists the students to reach the goal of collaborating learning in writing. The active asmosphere can be created and the way is by involving the learners in learning community. The innovation appears when all learners share the experience in writing. Sharing experiences mean share the way of writing, experience in writing, the problem and difficulties in writing, and so forth. In the research result, it says that the students are focusing towards their experience, with particularly positive opinions about its effects on English and teamwork skills so that they can be motivated in writing process and practice.

Chang, Rao, Stewart, Farley, and Katherine (2016) in their research state the importance of creating a faculty learning community to cultivate writing to learn practices, an inquiry and process-based writing pedagogy. It is stated clearly that all learners learn to write to practice together. They meet periodically to discuss how they implement the practices, and reflect on each other's instructional methods in the contexts of their own experiences. After a long process of learning, they share their experiences in writing. Shortly, the participation in learning community facilitates an engaging and effective way to learn and make use of new pedagogical practices. All learners obtain the practical adaptive strategies from each other; they feel supported and get deeper ways in writing.

Dean and Warren (2012) in their study find that community encourages a rich learning because of the interactions among many individuals, two-way exchange of ideas or information that is often called a real community. It is stated that the real community exists only when all members in community interact in a meaningful way that deepens their understanding of each others. The two things can occur as a result of writing and sharing, particularly informal writing.

Liu, Pardo, and Liu (2017) state that learning analytics helps to support students' engagement in collaborative writing. The learning analytic system is used to analyze the writing behaviors, and to create visualizations by incorporating individual engagement awareness and group ranking awareness (social affordance), and to review writing behaviour history (technological affordance). Their findings found that students agree with 
what the visualization conveys and visualizations enhance their engagement in a collaborative writing activity. Visualization is helpful to assist them in reflecting the writing process and supporting the assessment of each individual contributions.

Wilmot and Sioux (2018) also find the importance of writing community in learning to write. In the research result, it is stated clearly that students do not only feel empowered to develop their writing practices, but also are helped to transform identities as scholars. Developing writing practice means more time and space to practice a lot because of many peer learners; transforming identities mean they try to identify and dig their potency in writing. Therefore, writing groups can be said to provide the safe spaces where academic practices can be explicit and where they can be challenged.

Shi and Yang (2013) state that the observed collective lesson-planning conferences as the implimentation of a community of practice $(\mathrm{CoP})$ is carried on a local tradition to guide the learner in order to take a morally acceptable stand in their writing. It also deals with how the more and less experienced teachers should work together towards a sharing understanding of how to teach. The participating teachers in different experience and level try to work collaboratively in order to sustain the community coherence of pedagogical practice; they make any negotiations to develop the diversity of individual practices in the collective lesson-planning conferences. By doing $\mathrm{CoP}$, the learners are assisted in getting the deep understanding about the importance of sharing experiences so that such condition can complete and support the goal to write. Teachers in different class of knowledge attend together to guide their learners; the learners themselves share their experience in writing. Consequently, either teachers or learners get the new knowledge in increasing the writing competence.

\section{DISCUSSION}

The writing competence will be established when there is a continuous practice. The role of learning community for building writing competence is the main point to highlight. The research findings done by a number of researchers illustrate that writing is forming the habit. Habit can be formed when there is the facility for learning itself. One of the ways in forming the writing habit is through journal writing. It can be used to increase learners' confidence and performance in writing. Journal writing opens and provides the opportunity for reflection, improving essays, revealing troubles, and assisting the learners to bond with their teachers (Wanket, 2005). It means that the existence of learning community is essential and journal writing in learning community can be used to trigger students in writing.

Therefore, it is important to pay attention is that journal writing is the key point in starting to write. Journal writing can help learners in learning community. In journal writing through learning community, all learners try to focus what to write, create the awareness of writing, and so forth. After that, they share their writing experiences. 
Megumi (2016) states that through keeping a journal all learners become aware of errors they commonly make, increase their vocabularies, and become used to writing in English.

Florence and Yore (2002) mention that learning community triggers students in writing. Learning community has the role in initiating togetherness to interact with others. They learn together and share writing experiences. Such condition creates the flexible and relaxed atmosphere for learners in learning to write. Florence and Yore name it as co-authorship. Co-authorship in this context is to make the research report in which the role of the researcher supervisor, the role of the student (graduate and post-graduate), the interaction of the supervisor and the student, the activities and processes inherented in the co-authorship process, and the student's expertise, scientific writing, and entry into an academic discourse community are working together. Florence and Yore state that coauthoring a research report is an authentic and meaningful learning experience assisting the learners to write like scientists. What is talked about dealing with co-authorship has the significant impact towards learners' capacity in writing. Co-authorship functions to help learners to learn from different persons in different level of knowledge and experience in writing. Co-authorship shapes the learners to be able to trigger the learners so that each of them can position their role in learning to write.

Learning community in this context places every person as the learner to get the different experience of knowledge of writing; this is very helpful in creating the learners' mind to write better than before. Each person gets and shares each other, so learning community becomes the capital in improving the way of writing, the way of actualizing the ideas, the way of delivering the ideas, the way of giving argument towards the topic to discuss, and so forth. Such capacity will be able to be shaped; the learners get used to write in a better manner. The main point in learning community for producing the productive learners is that let all and every learner learns from their environment and gets the inspiration from the environment. The good enviroment named learning community in writing is a good place for them to think what to think and to write what to write.

All in all, learning community in writing is the good place for them to ask each other what every and all learners learn from the environment so that this place enriches the learners' knowledge in understanding writing as a thinking process. There will be no writing product if there is nothing to think and to discuss. This is the point in writing and learning community is the right place for them to learn. Shi and Yang (2013); Wilmot and Sioux (2018); Liu, Pardo, and Liu (2017); Dean and Warren (2012); Chang, Rao, Stewart, Farley, and Katherine (2016); Deveci (2018); and Schwehm, Saxton, and Stuckey (2017) in their researches state clearly that learning community in different approach gives the extraordinary effect for moving the learners in writing.

In addition to it, learning community is the triggerer which means that every person learning to write will be motivated by the others to be able to do the same thing. There are two sources triggering anyone to do the same thing relating to writing skill. Those are 
internal factor and external factor. The internal factor is commonly called internal motivation because the learner wants to learn and the internal motivation appears because of spirit for going ahead, reaching the target of life as the famous writer, and other internal motivations. The external factor is dealt with the urgent condition so that the learners should be able to write (Tuckman, 1991). For instance, those who have finished writing their dissertation must have the published article as the requirement to join the dissertation examination, thus they are obliged and forced to be able to write the academic writing. Dealing with the learning community, internal and external factor can appear together based on the need and condition. Whatever the required situation is, learning community contributes to the learners' target to be able to write well. Because learning community has the significant contribution for learners' achievment in writing, it is necessary to use it in writing class although Koba, Ogawa, and Wilkinson (2000) in their research discussed it dealing with speaking.

As the effort to use Community Language Learning (CLL) in learning community for writing, here are the principles of Larsen-Freeman \& Anderson (2011) that can be adopted:

1) Establishing the mutual relationship between the learners and the teacher in order to create a safe learning environment is important so that the students tend to learn more effectively when they feel secure;

2) The teacher stands behind, besides, and in front of the students in order to facilitate the learning process for triggering them to write what to write;

3) The teacher should respect the learners' level of confidence and transmit to them what needs to be done to be the successful writers. Giving motivation and sharing writing experiences are important to do;

4) As the teacher and the learners are whole persons, they can share learning experiences, thus getting to know one another and building a sense of community;

5) Each learner is unique so that the teacher as a counselor should be able to evaluate the learners and their ideas; the teacher always listens to them without giving any advice in order to understand how they feel about the learning process. The teacher attends as the loyal listener so that the teacher knows and understands their problems in writing;

6) All learners are required to attend to one task at a time and are offered a quiet reflection period in order to learn. It aims so that all learners share their writing experiences;

7) All learners have a choice in what they want to practice, as they have an inner wisdom about where they need to improve. The teacher's position is let them practice to write what must and should be written; 
8) Students work in a group and groups so that they can have the sense of belonging towards their community. They can learn each other and from the teacher;

9) The teacher should correct the errors that learners have produced in a nonthreatening way dealing with what they have written down;

10) By reading their sentences to the other members of the class and discuss them in the class with the teacher, all learners develop a sense of community and build trust helping to reduce the threat of the new learning situation. Learning from the previous writings is important for improvement and better writing;

11) Apart from the language, learners also reflect on what they have experienced. Thus, they have an opportunity to learn about the language, about their own learning, and about how to learn from one another in a community. By doing such steps, it enriches the learners' experiences in writing through learning community.

The above principles offer the beneficial concept of learning community in writing. Learning community helps students gain practical knowledge. Learning community is the indispensable component to school-based learning communities. It is necessary for instructors to bring it into classroom based and school-based learning communities in order to produce the educated learners who can perform well in writing (Zhu and Baylen, 2005:254). It is supported by Osbune (1985) that learning to write in community has the important role for all learners to learn each other. His findings illustate that when each student writes a composition in his or her native language on an assigned topic and the work is distributed; the class can compare writing systems and languages. Each of them presents the composition orally by paraphrasing, not translating. Class discussion covering the topic, organization, and role of the language used follow and is interesting. It helps the students get to know each other.

It means that the learning community used as the way of learning to write is the effective strategy that can be conducted. All learners learn to write, to share the problems in writing, and to share their writing experiences. The writing as the thinking process should be practiced frequently so that it can be the habit. The underlined point in learning community for writing practice is that every learner involved in writing activity should be able actualize the ideas in a concrete manner. The ability of actualizing the ideas in a concrete manner is the learners write what is able to write and to discuss what has been writtten in community in order to share the writing experiences. Sharing the writing experiences aims to open the collective perception that learning community helps the learners to be able to write in a better way.

Sharing the writing experiences used in learning community has the main goal so that all learners can build the same perception about the importance of writing experience. It is done for the sake of improvement. Something interesting to do is that learning community that is used to learn writing facilitates the learners to be open towards 
writing problems. To be open towards the learning problems means that every learners can identify and know the main problems that cause writing problems. Learning community used to facilitate learners in writing should be placed as the main point in discussing the main problems of writing. Learning community comprehended as the way of discussing the main problems of writing can be used the framework of anticipating the main problems of writing. Learning community is the open place for talking about the strategy of writing based on the problems the learners have. In learning community, the learners learn to find the strategy to write better because the appearing strategy comes to respond the problem.

Based on the discussion, it is very important to state that to be able to write correctly should be started from problems and difficulties in writing. It means that there is no way if there is no effort to find the way. It can be implemented towards an effort to be able to write. Delivering writing experiences through learning community will enrich the learners' knowledge about the writing experience of each learner as the writer. Each of them attends and shares the experience through learning community to say what to say, and to give the life experience of writing each other. By experiencing such condition, it will increase the learners' confidence. It is also important to note that in the process to be a good writer must undergo the problem and difficulties of writing. Becoming the novel writer needs the long process and it will be passed in an ease manner when every learner as the beginning writer wants to share his or her problems and difficulties in writing. Everyone in each identity is unique and the uniqueness can be the trait how someone is in the process of writing.

\section{CONCLUSION}

Learning community used to promote the writing experiences to trigger students to write is necessary to conduct. Learning community helps the learners to reduce the anxiety; it is helpful for the writing class in which all students have different levels of competence and achievment. All students in different levels of competence and achievment are identified based on their result of competence and achievment. After identification, the students with a high competence and achievment in writing helps to share to the low learners how they could perform better. The highly written competent learners should motivate the low learners so that they are interested and enthusiastic to learn writing.

\section{REFERENCES}

Andre G. Burne. (1985). L1 Writing for ESOL Composition. Paper presented at the annual meeting of Connecticut Teachers of English to Speakers of Other Languages (Meriden, Ct, April 12). Retrieved from 
https: / / eric.ed.gov/?q=Andre+G. +Burne.+(1985). + L1+Writing+for +ESOL+ Composition\&id=ED286351.

Azim Javadi-Safa. A Brief Overview of Key Issues in Second Language Writing Teaching and Research. (2018). International Journal of Education \&Literacy Studies, 6(2), 15-25.

Bruce W. Tuckman. (1991). Motivating college students: A model based on empirical evidence. Innovative Higher Education, 15(2), 167-176.

Chang, Mary K.; Rao, Kavita; Stewart, Maria L.; Farley, Cynthia A.; Li, Katherine. (2016). Towards Contextual Experimentation: Creating a Faculty Learning Community to Cultivate Writing-to-Learn Practices. Studying Teacher Education, 12(1), 20-36.

Dean, Deborah; Warren, Adrienne. (2012). Informal and Shared: Writing to Create Community. English Journal, 101(4), 50-54.

Erping Zhu and Danilo M. Baylen. (2005). From learning community to community learning: pedagogy, technology and interactivity. Educational Media International, 42(3), 251-268.

Florence Mokeira Okari. (2016). The Writing Skill in the Contemporary Society: The Kenyan Perspective. Journal of Education and Practice, 6(35), 65-69.

Fang-Yu Liao. (2017). The relationship between L2 students' writing experiences and their perceived poetry writing ability. Studies in Second Language Learning and Teaching, 7(4), 619-647.

Florence, Marilyn K.; Yore, Larry D. (2002). Learning To Write Like a Scientist. Paper presented at the Annual Meeting of the National Association for Research in Science Teaching (New Orleans, LA, April 7-10, 2002. Retrieved from https: / / eric.ed.gov/ ?q= writing+is + habit\&pg=15\&id=ED463957.

Jeremy Schwehm, Jennifer Saxton \& Annette Stuckey. (2017). Promoting Engagement and Community in Online Courses: It's all about the Writing. Conference Proceedings Adult Higher Education Alliance: Annual Conference, 41, 40-46.

Kirstin Wilmot and Sioux McKenna. (2018). Writing Groups as Transformative Spaces. Higher Education Research and Development, 37(4), 868-882.

Koba, N., Ogawa, N., \& Wilkinson, D. (2000). Using the community language learning approach to cope with language anxiety. The Internet TESL Journal. 6(11). Retrieved from http: / /iteslj.org/Articles/Koba-CLL.html.

Larsen-Freeman, D., \& Anderson, M. (2011). Techniques and principles in language teaching. (3rd ed.). London: Oxford University Press.

Ling Shi and Luxin Yang. (2014). A community of practice of teaching English writing in a Chinese University. System: An International Journal of Educational Technology and Applied Lingustics, 42(1), 133-142.

Linda S. Behar-Horenstein, Nadine Isaac, Charisse N., Michael E. Hudson-Vassell, Lian Niu, Melissa Pratto Alachua, Kellie W. Roberts, Robert J. Wingfield, Jeff D. Wolfgang, and Mueen A. Liu, Ming; Pardo, Abelardo; Liu, Li. (2017). Using Learning Analytics to Support Engagement in Collaborative Writing. International Journal of Distance Education Technologies, 15(4), 79-98.

Maureen O'Leary Wanket. (2005). Building the Habit of Writing. Educational Leadership, 63(1), 74-76. 
Megumi Kosaka. (2016). How I Have Improved My English Writing Skills. TESOL Journal, $7(2), 497-499$.

Tanju Deveci. (2018). Student Perceptions on Collaborative Writing in a Project-based Course. Universal Journal of Educational Research, 6(4), 721-732.

Zafar. (2016). Promoting Academic Socialization Through Service Learning Experiences. International Journal of Teaching and Learning in Higher Education, 28(2), 158-167. 